\title{
PERANCANGAN BUKU ILUSTRASI SEBAGAI MEDIA PENGENALAN BIDANG KEILMUAN DESAIN
}

\author{
Benny Rahmawan Noviadji ${ }^{1}$, Angga Hendrawan ${ }^{2}$ \\ Fakultas Desain, Institut Informatika Indonesia (IKADO) Surabaya ${ }^{2}$ \\ Penulis Korespondensi: Benny Rahmawan Noviadji, benny@ikado.ac.id, Surabaya, Indonesia
}

\begin{abstract}
Abstrak. Desain merupakan salah satu bidang ilmu pendidikan tinggi di Indonesia yang mengalami peningkatan minat cukup besar. Hal ini turut didukung dengan berlangsungnya revolusi industri 4.0 yang melibatkan peranan desain secara signifikan terhadap penciptaan lapangan kerja dan gaya hidup. Peningkatan minat terhadap bidang desain di Indonesia belum diikuti oleh keberadaan literatur khususnya buku yang membahas bidang desain secara utuh. Sebagian besar literatur masih sebatas membahas keterampilan teknis. Keberadaan buku yang membahas keterampilan konseptual masih tergolong minim. Hingga saat ini belum ada buku dari penulis lokal yang membahas bidang desain secara terpadu, sebagian justru menampilkan sepotong-sepotong rumpun ilmu di dalamnya. Berdasarkan permasalahan tersebut maka penelitian ini dilakukan untuk merancang dan menyusun sebuah buku sebagai literatur bidang desain. Metode yang digunakan pada perancangan ini adalah Research and Development dengan pendekatan model ADDIE, dengan tahapan sebagai berikut: 1) Analysis, 2) Design, 3) Development, 4) Implementation dan 5) Evaluation. Penelitian ini menghasilkan purwarupa berupa buku dengan pendekatan ilustrasi sebagai media sekaligus literatur untuk mengenalkan bidang keilmuan desain secara terpadu dan disajikan secara atraktif sehingga dapat memberikan motivasi belajar dan pemahaman bagi siswa Sekolah Menengah Atas/Kejuruan dan mahasiswa semester awal yang ingin mengetahui bidang desain dengan lebih luas.
\end{abstract}

Kata Kunci: Desain, Pendidikan, Buku Ilustrasi, Media Pembelajaran

\begin{abstract}
Design is one of the fields of higher education in Indonesia that has been a significant increase in interest. This is also supported by the ongoing industrial revolution 4.0 which involves a significant role in design in creating employment and lifestyles. The increasing interest in the field of design in Indonesia has not been followed by the existence of literature, especially books that discuss the field of design in its entirety. Most of the literature is still limited to technical skills. The existence of books which discuss conceptual skills is still lacking. Until now, there have been no books from local authors that discuss the field of integrated design, some of which present bits of knowledge in it. Based on these problems, this research was conducted to design and compile a book as design literature. The method used in this design is Research and Development with the ADDIE model approach, with the following stages: 1) Analysis, 2) Design, 3) Development, 4) Implementation and 5) Evaluation. This research produces a prototype in the form of a book with an illustration approach as a medium as well as literature to introduce the science of integrated design that is presented attractively so that it can provide learning motivation and understanding for high school / vocational high school students and first year students who want to know the field of design more broadly.
\end{abstract}

Keyword: Design, Education, Illustration book, Learning media 


\section{Pendahuluan}

Kata "desain" adalah kata baru yang diindonesiakan dari bahasa inggris: design. Sebetulnya kata "rancang" atau "merancang" adalah terjemahan yang dapat digunakan. Namun dalam perkembangannya kata "desain" menggeser makna kata "rancang" karena kata tersebut tidak dapat mewadahi kegiatan, keilmuan, keluasan dan pamor profesi atau kompetensi Desainer (Sachari and Sunarya 2000). Ruang lingkup desain dapat disederhanakan ke dalam lima pembagian, yaitu: objek, komunikasi, lingkungan, sistem dan identitas. Desain sebagai kata kerja berarti proses penciptaan objek baru, sedangkan sebagai kata benda desain berarti hasil akhir sebuah proses kreatif baik dalam wujud rencana, proposal, atau karya desain sebagai objek nyata. Ruang lingkup ini lebih dikenal sebagai ranah desain produk (Sakti 2018). Dalam lingkup komunikasi, desain sebagai alat komunikasi yang efektif dengan mengenali dan memahami macam-macam bentuk, warna dan simbol yang tergambar dalam sebuah desain grafis baik berupa gambar grafis maupun gambar manual. Secara umum ruang lingkup ini lebih dikenal sebagai ranah desain grafis atau desain komunikasi visual (Saifudin 2013). Dalam lingkup lingkungan, desain juga dapat merujuk kepada seni terapan dan ilmu yang berhubungan dengan menciptakan lingkungan manusia dirancang. Istilah desain telah diperluas untuk diterapkan pada isu-isu ekologi dan keberlanjutan (123desaingrafis 2013). Dalam lingkup sistem, desain dapat didefinisikan sebagai kebutuhan fungsional untuk mempersiapkan rancang bangun berupa penggambaran, perencanaan dan pembuatan sketsa atau pengaturan dari beberapa elemen terpisah ke dalam satu kesatuan utuh dan berfungsi. Pada lingkup identitas, Desain sangat dibutuhkan kehadirannya di sini, karena wajah pertama sebuah perusahaan yang dilihat oleh masyarakat adalah produk desain visualnya (Alodia 2019).

Desain menekankan bahwa aktivitas desain berfokus pada perilaku manusia dan relasinya terhadap kualitas hidup manusia. Pengaruh lingkungan alam untuk manusia tidak dapat dipisahkan dari pengaruh lingkungan alam terhadap objek yang diciptakan, dibuat, dan digunakan oleh manusia. Pengaruh alam dibedakan berdasarkan konteks genetik dan konteks alam (Giard 2016). Desain adalah kegiatan kreatif yang menyusun rencana dan rancangan untuk suatu benda, gambar atau objek lainnya sebelum direalisasikan menjadi nyata agar memiliki nilai lebih, kenyamanan yang lebih baik dan diterima oleh penggunanya. Desain adalah suatu rencana yang terdiri dari beberapa unsur untuk mewujudkan suatu hasil yang nyata. Jika melihat dari hakikat desain yang selalu menyebutkan hasil produknya, maka desain tidak dapat berhenti di atas kertas. Desain merupakan aktivitas praktis yang akan diterbitkan ke masyarakat. Secara natural desain juga akan bersinggungan dengan unsur-unsur ekonomi, sosial, teknologi dan budaya dengan berbagai dinamikanya. Sehingga desain yang baik juga harus sesuai dengan kebutuhan masyarakat. Di samping itu penerimaan masyarakat tersebut kepada suatu desain haruslah kritis, tanpa apresiator yang kritis tidak akan terjadi pertumbuhan desain yang sehat. Dengan begitu desain bukanlah ilmu yang dapat berdiri sendiri, sejatinya desain adalah lintas disiplin ilmu, setidaknya antara Seni, Sains, Teknologi dan Sosiologi. Sebagaimana dikemukakan oleh Sachari and Sunarya $(2001,10)$ bahwa "Desain adalah terjemahan fisik mengenai aspek sosial, ekonomi, dan tata hidup manusia, serta merupakan cerminan budaya zamannya. Desain adalah salah satu manifestasi kebudayaan yang berwujud, desain adalah produk dari nilai-nilai yang berlaku pada kurun waktu tertentu."

Secara umum terdapat beberapa tujuan yang harus dicapai oleh desain yang baik. Sebetulnya tujuan tersebut sangat tergantung pada desain apa yang ingin diciptakan, misalnya desain produk memiliki tujuan yang lebih spesifik (Thabroni 2019). Namun ada beberapa tujuan umum yang mencakup seluruh cabang desain, tujuan-tujuan tersebut adalah: 1) Tercapainya fungsionalitas yang efektif dan efisien, 2) Sebagai identitas (brand), 3) Menjaga benda yang akan dibuat (quality control), 4) Kenyamanan Inderawi: tampilan yang estetis, 5) Menambah nilai 
benda yang akan dirancang, 6) Mencapai kenyamanan fisik (ergonomis), 7) Memberikan nilai dan makna yang ingin disampaikan, 8) Menyampaikan gagasan yang ingin disampaikan. Proses desain harus mampu memberi gambaran tentang keterkaitan tujuan dan fungsi yang sesuai sehingga dapat dijadikan pedoman untuk menyusun konsep dari luaran desain. Adapun fungsi dari desain adalah sebagai berikut: 1) Merupakan sebuah proses untuk membuat atau menciptakan obyek baru, 2) Merupakan sebuah ilmu pengetahuan dan wawasan kepada manusia, supaya bisa mengerti bentuk dalam bentuk penggambaran bidang, ruang, susunan, konfigurasi, komposisi, nilai dan sebagainya, 3) Merupakan sebuah alat untuk mengkomunikasikan suatu karya cipta baru seorang desainer kepada masyarakat umum, 4) Merupakan sebuah wadah untuk menampilkan objek-objek kepada masyarakat dengan suatu gambaran ataupun nyata (seputarpengetahuan.co.id 2017).

Dalam rangka mencapai tujuan yang diharapkan, perlu menerapkan metode desain guna menjalankan aktivitas desain. Metode Berpikir Desain atau Design Thinking Methods adalah metode yang banyak digunakan untuk menyelesaikan permasalahan desain bahkan juga permasalahan di luar desain. Design thinking merupakan sebuah pendekatan dalam membuat sebuah pengalaman yang menyangkut dampak emosional, estetika, serta interaksi yang berorientasi terhadap nilai sosial. Terdapat beberapa versi tahapan dalam proses design thinking, namun pada prinsipnya adalah sama yaitu memberikan gambaran melalui tahapantahapan bagaimana menciptakan sebuah desain inovatif yang didasari dari permasalahan spesifik kebutuhan manusia, serta menghasilkan solusi yang dapat diaplikasikannya secara umum. Ambrose and Harris $(2010,22)$ mengadopsi metode design thinking menjadi tujuh kerangka berpikir dalam perancangan produk yang sistematis. Tujuh tahapan tersebut adalah 1) exploration, 2) identification, 3) ideation, 4) visualisation, 5) prototyping, 6) evaluation, dan 7) persuation. Ingle (2013) membagi proses design thinking menjadi empat fase kerangka berpikir, meliputi 1) understanding, 2) define, 3) ideate, 4) prototype and test. Sedangkan Brown and Wyatt $(2010,29-35)$ menekankan bahwa design thinking merupakan sebuah interaksi yang berorientasi pada manusia (human oriented), yang di dalamnya ada proses 1) emphaty, 2) integrative thinking, 3) optimism, 4) experimentalism, dan 5) collaboration (hubungan yang mendalam) yang semuanya itu digambarkan/dipetakan menjadi 3 pilar penting dari proses berpikir desain. Ketiga bagian tersebut adalah inspiration, ideation, dan implementation.

\section{Multidisiplin Desain}

Desain sebagai cabang keilmuan, menurut Walker bahwa secara epistemologi ilmu-ilmu desain bukan merupakan ilmu otonom, yang mencukupi di dalam dirinya sendiri, tetapi merupakan ilmu yang dibangun melalui 'peminjaman' dari pelbagai keilmuan lainnya (Piliang 2010, 11). Dengan perkataan lain, ilmu desain dibangun oleh 'arsitektur' keilmuan yang mengombinasikan aneka bidang keilmuan pinjaman lainnya sebagai kesatuan ilmu desain, sebagaimana dapat dijelaskan melalui skema berikut: 


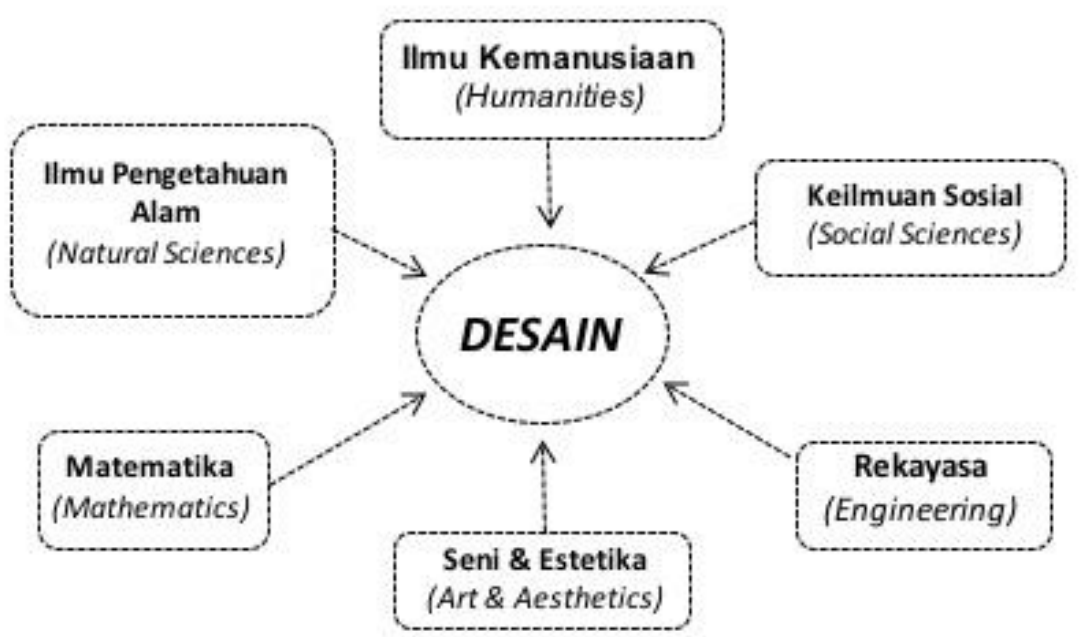

Gambar 1 Hubungan Keilmuan Desain dengan Keilmuan Lain Sumber : (Piliang 2010, 11)

Berdasarkan skema di atas menjelaskan bahwa ciri khusus dan ilmu-ilmu desain adalah sifatnya interdisipliner, yang melibatkan pelbagai cabang keilmuan lain, dalam intensitas tertentu dan dalam bentuk yang khusus seperti ilmu pengetahuan alam (fisika, kimia dan biologi), matematika, rekayasa (teknik mesin, teknik elektro, dan sebagainya), ilmu-ilmu sosial (sosiologi, ekonomi, politik dan hukum), ilmu kemanusiaan (bahasa, komunikasi, psikologi, antropologi, filsafat), serta estetika dan ilmu-ilmu seni.

Desain tidak menghasilkan satu interpretasi seperti sains. Desain bersifat multidisiplin yang berkaitan dengan banyak faktor dan disiplin ilmu pengetahuan lain. Karena desain selalu dihadapkan pada sesuatu yang baru dan kondisi yang berubah-ubah, maka desain selalu bekerja secara divergen. Desain bekerja dengan mengolah beragam disiplin yang berkaitan dengan masalah yang dihadapi, kemudian menghasilkan alternatif solusi dan melakukan pengembangan pada solusi tersebut secara terus-menerus. Hasil desain dan prosesnya sering menghasilkan wacana dan perdebatan (Buchanan 1995, 25). Desain bukan memikirkan sesuatu, tetapi berpikir bagaimana cara memikirkan sesuatu. Hasil yang diharapkan adalah solusi baik produk atau sistem.

Desain merupakan salah satu alat untuk memadukan tiga pilar keilmuan yang meliputi seni, sains dan teknologi. Charles W. Morris menyebutnya sebagai intellectual integration. Melalui pendekatan ini maka kita bisa menempatkan seni, kriya, engineering, teknologi, sains alami dan sains sosial pada tempatnya masing-masing. Seni dan kriya masuk dalam art, engineering teknologi masuk dalam technology, sains alami dan sains sosial masuk dalam sience. Saat desain diartikan sebagai aktifitas olah pikir untuk menghasilkan sesuatu, maka desain dapat disebut sains. Desain berdasar pada sains, dan desain memperpanjang jangkauannya dalam memenuhi kebutuhan emosional melalui estetika (Buchanan 1995, 53).

\section{Desain dan Pendidikan Tinggi}

Desain merupakan salah satu bidang ilmu pendidikan tinggi di Indonesia yang di dalamnya terdapat beragam fokus misalnya: desain grafis, desain komunikasi visual, desain produk, dan desain interior. Pendidikan desain memberikan keterampilan teknis hingga ke keterampilan konseptual kepada para mahasiswa, sehingga para mahasiswa dapat menempati posisi-posisi tertentu di suatu perusahaan setelah menyelesaikan pendidikannya. Keterampilan teknis dibentuk melalui mata kuliah praktikum yang sebagian besar memanfaatkan perangkat keras 
dan perangkat lunak komputer, sedangkan kemampuan konseptual dibentuk melalui mata kuliah yang mengajarkan tentang penggunaan elemen desain untuk mencapai tujuan.

Seiring berjalannya waktu, apabila dilihat di tahun belakangan ini terdapat peningkatan minat terhadap pendidikan desain, hal ini tercermin dari banyaknya perguruan tinggi negeri atau swasta yang membuka program studi pada bidang ilmu desain. Peningkatan minat terhadap pendidikan desain turut didukung oleh berlangsungnya revolusi industri 4.0 yang kebetulan melibatkan bidang desain secara signifikan. Anak-anak muda diberikan kemudahan untuk mengekspresikan dirinya melalui berbagai macam aktivitas di dunia nyata maupun dunia maya, bahkan sekaligus menekuninya sebagai profesi, hal ini tentu sejalan dengan bidang desain yang turut membentuk gaya hidup masyarakat sehingga pada anak-anak muda lebih familiar dan tertarik dengan desain.

Peningkatan minat terhadap pendidikan desain sayangnya belum diikuti oleh keberadaan literatur yang memadai. Sebagian besar literatur desain di Indonesia masih didominasi oleh pembelajaran teknis atau bersifat tutorial, sedangkan pembelajaran yang bersifat konseptual relatif berdiri sendiri-sendiri dan juga memiliki kecenderungan mengajarkan ketrampilan teknis, padahal desain merupakan interdisiplin yang melibatkan berbagai keilmuan dalam menjalankan perannya. Sampai saat ini belum terdapat buku desain dari penulis lokal yang membahas bidang desain secara terpadu serta disajikan secara atraktif dan menarik, hal ini secara tidak langsung berpengaruh terhadap proses pendidikan. Literatur yang seharusnya membuka gambaran utuh tentang bidang ilmu desain, justru cenderung memberikan pengetahuan yang sepotongsepotong bagi pembacanya.

Berdasarkan permasalahan yang telah diuraikan di bagian sebelumnya, penulis melihat peluang untuk merancang literatur berupa buku tentang bidang keilmuan desain secara terpadu, lengkap serta disajikan secara menarik dan atraktif. Melalui buku ini diharapkan lulusan sekolah menengah atas/kejuruan yang ingin mengenyam pendidikan desain atau mahasiswa semester awal, akan memiliki perspektif yang lebih luas tentang desain dan interkoneksinya dengan bidang keilmuan lainnya serta lebih mudah memahami isi buku. Buku ilustrasi berbeda dengan buku literatur pada umumnya.

Buku ilustrasi memiliki kemampuan untuk menerangkan dengan mudah. Adapun fungsi ilustrasi dalam perancangan buku antara lain (Arifin and Kusrianto 2009, 70-71) memiliki fungsi Deskriptif, yaitu sebagai pengganti uraian tentang sesuatu secara verbal dan naratif dengan menggunakan kalimat panjang. Fungsi Ekspresif yaitu dengan ilustrasi dapat memperlihatkan dan menyatakan suatu gagasan, maksud, perasaan, situasi atau konsep yang abstrak menjadi nyata secara tepat dan mengena. Fungsi Analitis / Struktural yaitu dengan ilustrasi dapat menunjukkan rincian bagian demi bagian dari suatu benda, sistem atau proses secara detail. Terakhir fungsi Kualitatif, yaitu ilustrasi biasanya menggunakan daftar, tabel, grafis, kartun, foto, gambar, sketsa, skema dan simbol. Perancangan buku literatur desain dengan pendekatan ilustrasi diharapkan dapat membantu dan memudahkan pembaca dalam memahami materi, sehingga informasi lebih cepat tersampaikan. Keakuratan data dan desain buku yang baik membantu keefektifan komunikasi visual sebuah buku (Lukman et al. 2009, 9).

Ditinjau dari segi isi, buku ini nantinya akan terbagi menjadi 10 (sepuluh) bagian utama sebagai berikut: 1) transformasi desain, 2) pemahaman desain, 3) faktor desain alamiah, 4) faktor desain artifisial, 5) aspek tujuan desain, 6) aspek fungsi desain, 7) aspek wujud desain, 8) proses desain, 9) perangkat desain, 10) penutup, yang nantinya pada masing-masing bagian tersebut diuraikan dalam bentuk teks dan gambar.

Buku ilustrasi ini juga harus melalui proses desain yang baik, sehingga para pembaca menangkap bahwa buku ini tidak hanya memberikan pengetahuan tentang desain tetapi turut menerapkan desain itu sendiri. Buku ini akan dirancang sebagai "buku ilustrasi" sehingga dapat memberikan pengalaman membaca buku secara menyenangkan karena konsep visualnya. 


\section{Metode}

Metode yang digunakan pada perancangan ini adalah Research and Development dengan pendekatan model ADDIE, yang di dalamnya terdapat tahapan sebagai berikut: 1) Analysis, 2) Design, 3) Development, 4) Implementation dan 5) Evaluation (Chaeruman 2008). Berdasarkan metode desain yang digunakan, disusun kerangka penelitian sebagai berikut:

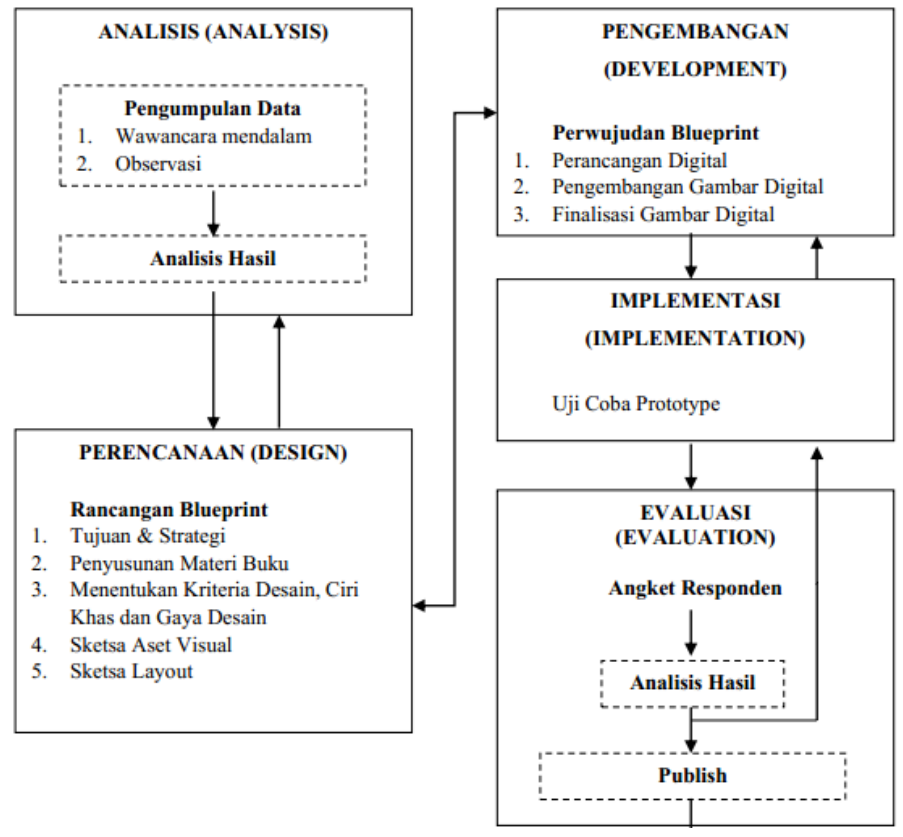

Gambar 2 Sistematika Perancangan

\section{Tahap Analisis (analysis)}

Tahap ini merupakan proses analisis kebutuhan, mengidentifikasi masalah (kebutuhan), dan melakukan analisis tugas. Tahap analisis merupakan langkah awal untuk menganalisis kelemahan sistem pembelajaran saat ini. Tahap ini dilakukan melalui aktivitas observasi, dokumentasi dan wawancara mendalam. Sejumlah Informasi yang terkumpul akan dianalisis sehingga dapat digunakan sebagai bahan pertimbangan dalam menentukan materi dan konten buku ilustrasi/visual.

Langkah pertama adalah melakukan wawancara untuk mendapatkan data pendukung dari dosen dan mahasiswa Fakultas Desain untuk mengumpulkan informasi sebagai data pendukung mengenai kebutuhan buku yang efektif digunakan untuk proses perkuliahan terkait dengan bidang desain, lalu diteruskan dengan berbagai kegiatan seperti observasi dan sebagainya.

\section{Tahap Desain (design)}

Tahap ini melakukan proses perancangan secara keseluruhan meliputi desain media secara materi dan visual. Beberapa tahapan kegiatan yang dilakukan antara lain:

1. Menentukan tujuan dan strategi media pembelajaran bagi mahasiswa agar mencapai tujuan yaitu menghasilkan sebuah buku ilustrasi tentang bidang keilmuan desain secara terpadu sebagai literatur dan media ajar yang efektif dan tepat digunakan oleh dosen dan mahasiswa. Tepat dalam hal ini adalah efektif dalam hal penyajian materi yang sesuai, sistematis dan lengkap, serta menarik dalam hal penyajian sehingga mampu merangsang mahasiswa agar tertarik dalam belajar.

2. Menyusun materi sesuai kurikulum menjadi materi yang padat dan jelas yang akan dibahas dalam buku. Pada tahap ini juga menentukan judul buku, kriteria, ciri khas dan gaya desain 
untuk tampilan buku secara global. Penyusunan materi ini juga berdasarkan hasil observasi dari beberapa buku yang membahas topik serupa, serta materi perkuliahan yang digunakan oleh dosen dalam mengajar. Judul dari buku ilustrasi untuk mengenalkan bidang keilmuan desain ini adalah "Berdesain: Teori dan Praktik Desain". Buku ini berisikan 10 (sepuluh) bagian utama sebagai judul-judul bab, yang sudah ditetapkan antara lain memuat tentang: 1) Transformasi Desain: Penjelasan tentang perkembangan bentuk desain dari era prasejarah hingga postmodern. 2) Pemahaman Desain: Penjelasan definisi desain dari empat perspektif dan ruang lingkup desain. 3) Faktor Desain Alamiah: Penjelasan tentang faktor-faktor alamiah yang mempengaruhi desainer dalam menentukan keputusan desain. 4) Faktor Desain Artifisial: Penjelasan tentang faktor-faktor buatan yang mempengaruhi desainer dalam menentukan keputusan desain. 5) Tujuan Desain: Penjelasan tentang tujuan yang mendasari pengguna untuk memutuskan menggunakan suatu luaran desain. 6) Fungsi Desain: Penjelasan tentang fitur yang harus ada pada suatu luaran desain sehingga tujuan dapat tercapai. 7) Elemen Desain: Penjelasan tentang elemen desain dan konfigurasinya. 8) Proses Desain: Penjelasan tentang tahapan-tahapan yang harus dilalui sehingga dapat terbentuk luaran desain yang komprehensif. 9) Perangkat Desain: Penjelasan tentang perangkat-perangkat yang dapat digunakan untuk menunjang kegiatan desain. 10) Penutup: Kesimpulan dari seluruh bagian buku dan pesan penulis. Tabel 1 Pembagian BAB isi buku.

\begin{tabular}{|c|c|c|}
\hline Bagian / BAB & Sub Bab & Sus-sub Bab \\
\hline Bagian/BAB 1 & Transformasi Desain & $\begin{array}{ll}\text { A. } & \text { Adaptasi } \\
\text { B. } & \text { Substitusi } \\
\text { C. } & \text { Eksistensi } \\
\text { D. } & \text { Modifikasi } \\
\text { E. } & \text { Abstraksi } \\
\text { F. } & \text { Profesi } \\
\text { G. } & \text { Industrialisasi } \\
\text { H. } & \text { Rasionalisasi }\end{array}$ \\
\hline Bagian/BAB 2 & Pemahaman Desain & $\begin{array}{ll}\text { A. } & \text { Desain sebagai Bidang } \\
\text { B. } & \text { Desain sebagai Aktifitas } \\
\text { C. } & \text { Desain sebagai Konsep } \\
\text { D. } & \text { Desain sebagai Wujud } \\
\text { E. Ruang Lingkup Desain } \\
\text { F. } & \text { Asosiasi Desain }\end{array}$ \\
\hline Bagian/BAB 3 & Faktor Desain Alamiah & $\begin{array}{l}\text { A. Faktor Lingkungan } \\
\text { B. Faktor Manusia }\end{array}$ \\
\hline Bagian/BAB 4 & Faktor Desain Artifisial & $\begin{array}{ll}\text { A. } & \text { Religi } \\
\text { B. } & \text { Pengetahuan } \\
\text { C. } & \text { Teknologi } \\
\text { D. } & \text { Organisasi Sosial } \\
\text { E. } & \text { Mata Pencaharian } \\
\text { F. } & \text { Bahasa } \\
\text { G. } & \text { Kesenian }\end{array}$ \\
\hline Bagian/BAB 5 & Tujuan Desain & $\begin{array}{l}\text { A. Mengakomodir Kebutuhan } \\
\text { B. Mengakomodir Nilai } \\
\text { C. Mengakomodir Makna }\end{array}$ \\
\hline Bagian/BAB 6 & Fungsi Desain & $\begin{array}{ll}\text { A. } & \text { Keindahan } \\
\text { B. } & \text { Kebergunaan } \\
\text { C. } & \text { Keselamatan } \\
\text { D. } & \text { Aksesbilitas } \\
\text { E. } & \text { Keterjangkauan } \\
\text { F. } & \text { Keberlanjutan } \\
\text { G. } & \text { Ketahanan } \\
\text { H. } & \text { Identitas } \\
\text { I. } & \text { Emosional } \\
\text { J. } & \text { Simbolisasi }\end{array}$ \\
\hline Bagian/BAB 7 & Elemen Desain & A. Elemen Abstrak \\
\hline
\end{tabular}




\begin{tabular}{|c|c|c|c|}
\hline & & & Atribut Elemen \\
\hline & & c. & Struktur Elemen \\
\hline & & D. & Reproduksi Elemen \\
\hline & & E. & Relasi Elemen \\
\hline Bagian/BAB 8 & Proses Desain & A. & Tahap Penetapan Masalah \\
\hline & & B. & Tahap Pengumpulan Informas \\
\hline & & c. & Tahap Penciptaan Ide \\
\hline & & D. & Tahap Membangun Prototipe \\
\hline & & E. & Tahap Penentuan Pilihan \\
\hline & & F. & Tahap Implementasi \\
\hline & & G. & Tahap Evaluasi \\
\hline Bagian/BAB 9 & Perangkat Desain & A. & Perangkat Konvensional \\
\hline 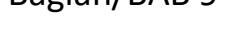 & & B. & Perangkat Elektronik \\
\hline & & c. & Perangkat Lunak \\
\hline & & D. & Perangkat Intelektual \\
\hline Bagian/BAB 10 & Penutup & A. & Kesimpulan \\
\hline & & B. & Saran \\
\hline
\end{tabular}

Sumber: Penulis.

3. Menentukan konsep sampul buku dan konsep layout buku. Setelah itu membuat beberapa alternatif sketsa sampul dan sketsa layout buku sebelum diwujudkan secara digital menggunakan software yang diperlukan. Hasil dari tahap ini akan digunakan sebagai acuan dalam proses layouting menggunakan software Adobe In Design. Pada tahap ini hanya merencanakan alternatif layout, pembagian letak teks dan gambar, jenis typeface pada sub headline maupun bodycopy, serta warna khas pada elemen visual yang ditampilkan.

\section{Tahap Pengembangan (development)}

Tahap pengembangan (development) adalah tahap dalam mewujudkan rancangan atau desain sebagai perwujudan pada tahap sebelumnya melalui proses digital. Beberapa tahapan kegiatan yang dilakukan antara lain: proses perancangan digital aset-aset visual dari sketsa terpilih, proses image editing dan pengembangan digital terhadap aset-aset visual, hingga penerapan komposisi layout. Pada tahap ini terus dilakukan uji coba, perbaikan dan pengembangan lanjut sebelum diimplementasikan sehingga sesuai dengan peran dan fungsinya.

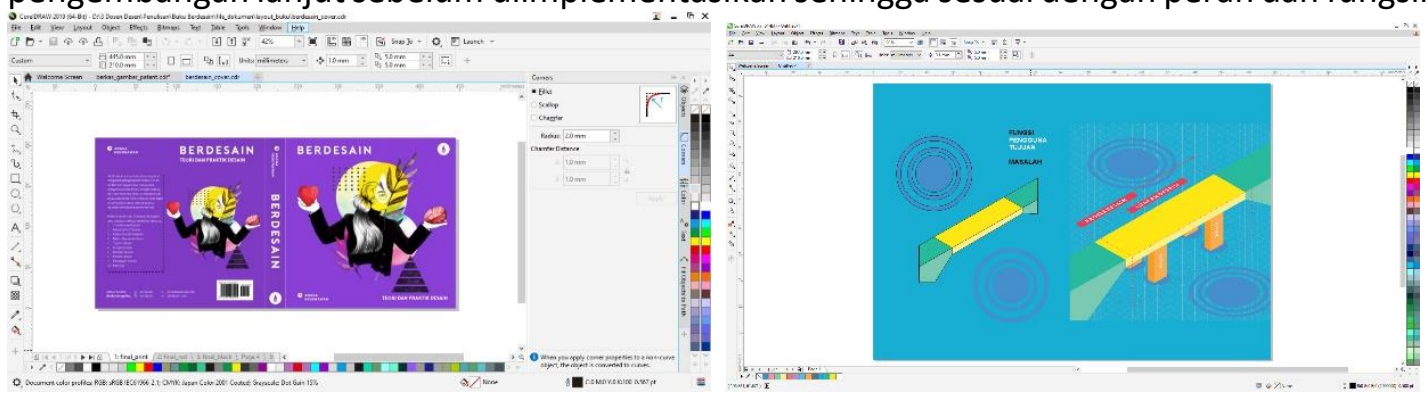

Gambar 3 Proses Membuat Gambar Vector Menggunakan Corel Draw
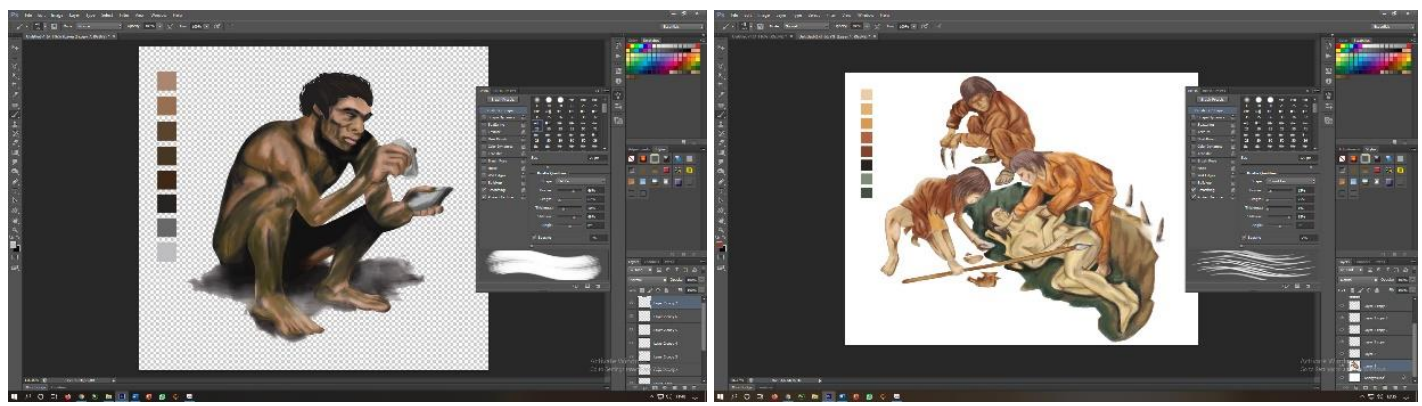

Gambar 4 Proses Reproduksi Aset Visual Menggunakan Adobe Photoshop dan Digitizer 


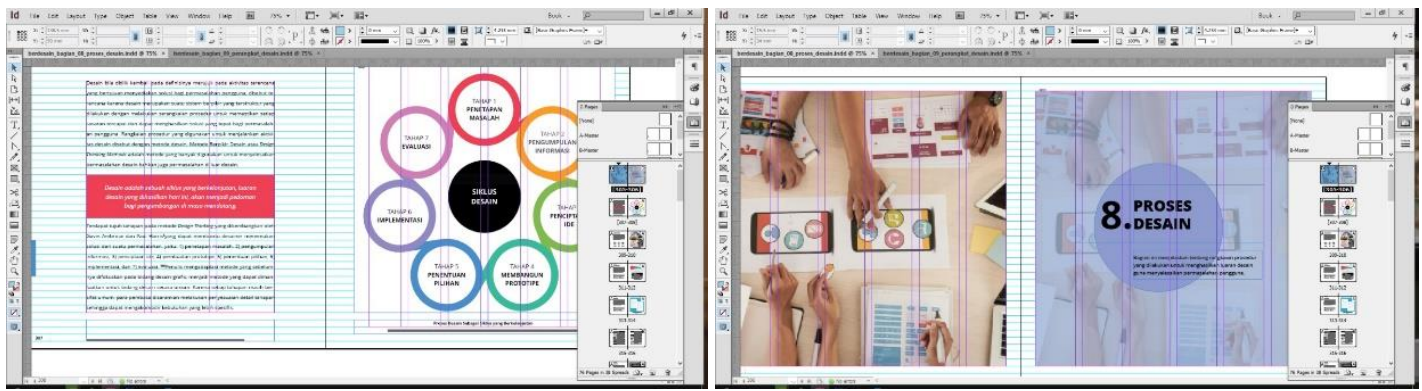

Gambar 5 Proses Layout Isi Buku Menggunakan Adobe In Design

Tahap Implementasi (implementation)

Purwarupa buku ilustrasi Berdesain diimplementasikan kepada mahasiswa semester awal program studi Desain Komunikasi Visual IKADO Surabaya sebagai target pengguna pada saat melakukan sistem pembelajaran secara online, khususnya pada mata kuliah dasar desain di semester awal. Implementasi menitikberatkan pada respon mahasiswa terhadap nilai fungsional serta tampilan visual pada setiap elemen desain yang terdapat dalam buku. Tahap ini bertujuan untuk mendapatkan informasi serta tanggapan responden terhadap penyempunaan buku agar tercapai tujuan yang diharapkan. Informasi yang digali dari tahap uji coba ini adalah berkaitan dengan apakah buku ilustrasi sebagai media penunjang pembelajaran telah sesuai tujuan yang diharapkan ataukah belum.

\section{Tahap Evaluasi (evaluation)}

Tahap evaluasi yang dilakukan adalah penilaian hasil uji coba meliputi penilaian menggunakan metode kuisioner kepada responden. Data diolah menggunakan metode distribusi frekuensi berdasarkan frekuensi (Fi) dan frekuensi relatif (\%). Aspek penilaian yang diberikan meliputi segi fungsional, tampilan/desain dan efektivitas media.

\section{Hasil dan Pembahasan}

Buku ilustrasi "Berdesain: Teori dan Praktik Desain" secara keseluruhan berjumlah 484 halaman termasuk lampiran, yang tersusun menjadi 10 (sepuluh) bagian pokok pembahasan tentang desain, dimana pada keseluruhan bagian tersebut membahas beberapa sub pokok bahasan yang disajikan secara efektif dan didominasi oleh unsur visual berupa ilustrasi.

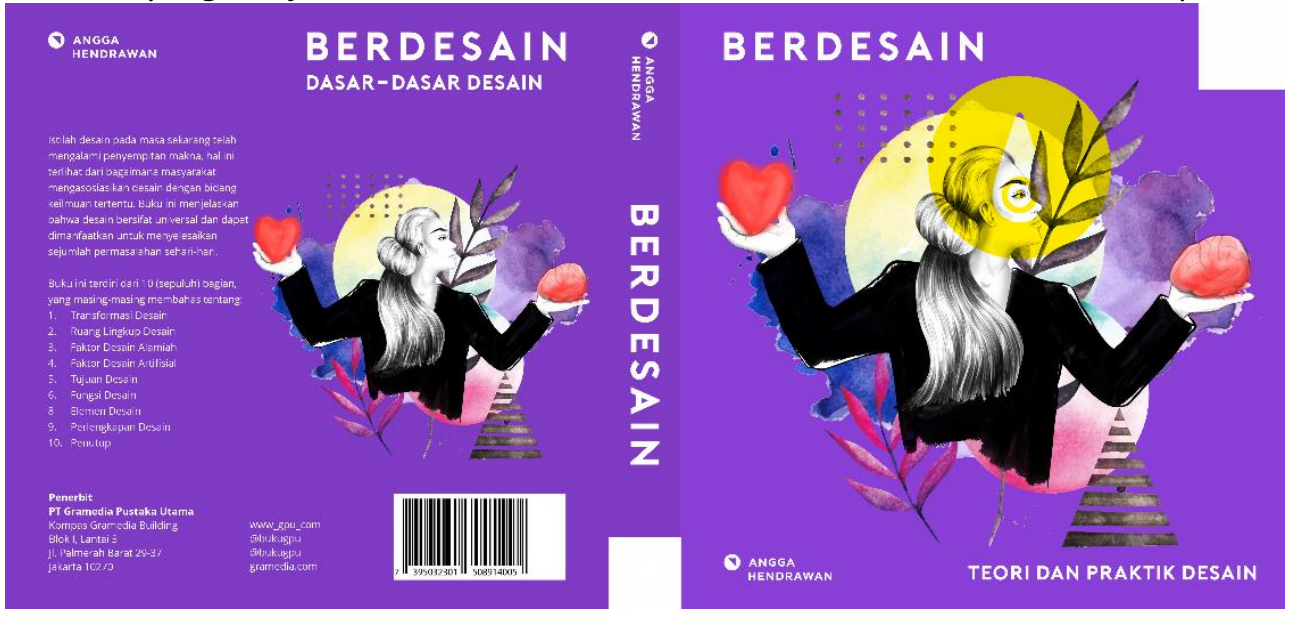

Gambar 6 Sampul Buku Ilustrasi "BERDESAIN: Teori dan Praktik Desain” 
Konsep desain sampul buku ilustrasi Berdesain menggambarkan seorang androgini (pria) yang memiliki postur ramping wanita yang rambutnya diikat (semacam konde) namun sebagian rambut lainnya terurai, memiliki dada bidang namun bentuk tubuhnya menyerupai wanita yang feminim, dengan pakaian yang dikenakan adalah unisex. Tampak dari samping dengan kedua tangannya yang masing-masing membawa kreativitas (tangan kanan) dan logika (tangan kiri). Pada bagian kepala terdapat lingkaran suci berwarna kuning (logo Berdesain) yang bagian lingkaran kecilnya tepat berada di bagian mata. Di sela-sela karakter tersebut muncul elemen estetik yang menggambarkan keindahan, kreativitas dan logika, yang tampilkan dengan bunga, mistar/penggaris, pensil, dan lain sebagainya.

Isi buku lebih menjelaskan desain secara umum, disertai dengan contoh-contoh berupa gambar yang dapat memudahkan pembaca untuk memahaminya. Buku ilustrasi "Berdesain: Teori dan Praktik Desain" memiliki ciri khas layout yaitu pada halaman bagian kiri berupa bodytext dan halaman bagian kanan berupa ilustrasi. Keutuhan buku terbagi menjadi beberapa bagian yang terdiri dari bagian awal buku, bagian isi yang menjelaskan materi tentang keilmuan desain, dan bagian lampiran dan informasi.

\section{Bagian 01 - Transformasi Desain}

Bagian ini menjelaskan perkembangan bentuk desain dimulai dari kehidupan manusia purba sampai di kehidupan manusia modern seperti sekarang. Isi pada bagian ini menggambarkan tentang transformasi desain berdasarkan rekam jejak manusia dari era prasejarah hingga masuk ke era post-modern. Kesepuluh poin transformasi tersebut yaitu: 1) adaptasi; 2) substitusi; 3) eksistensi; 4) modifikasi; 5) abstraksi; 6) profesi; 7) industrialisasi; 8) rasionalisasi; 9) segmentasi; dan 10) konseptualisasi. Bagian ini banyak menampilkan ilustrasi artefak-artefak dari berbagai literatur, yang kemudian direproduksi atau digambar ulang menggunakan teknik digital drawing.

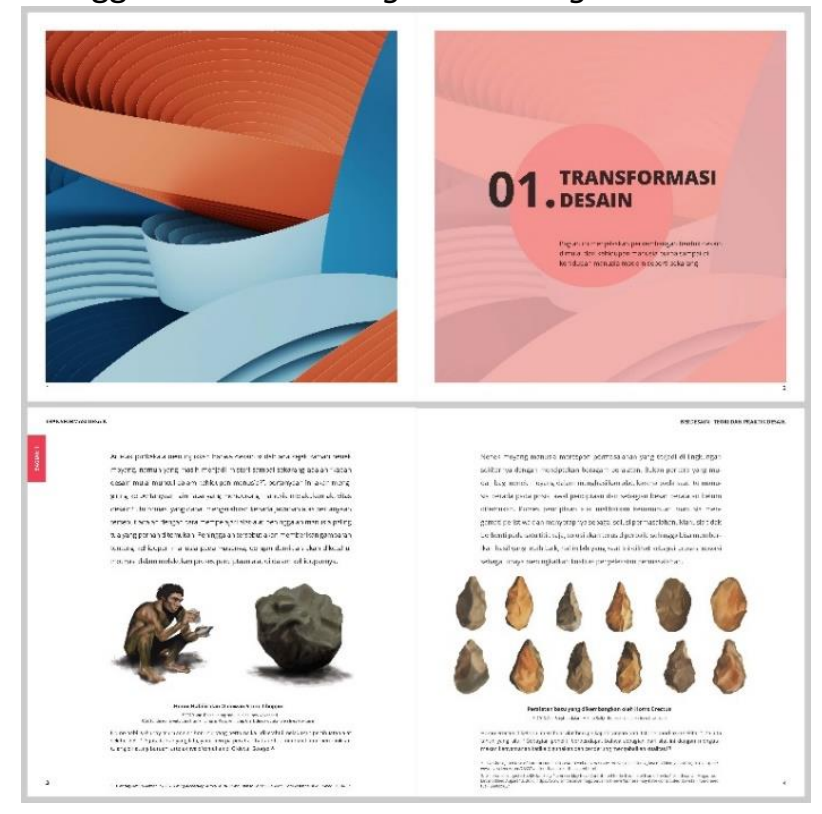

Gambar 7 Bagian Kesatu - Transformasi Desain

\section{Bagian 02 - Pemahaman Desain}

Bagian ini menjelaskan tentang pengertian desain dilihat dari empat perspektif, ruang lingkup desain dan asosiasi yang berkaitan dengan lingkup desain. Keempat sudut pandang tersebut yaitu: 1) desain sebagai bidang, 2) desain sebagai aktivitas, 3) desain sebagai konsep, 4) desain sebagai wujud. Keempat sudut pandang desain tersebut harus memperoleh perhatian 
secara seimbang sehingga desainer mampu menawarkan solusi yang tepat sasaran. Pada masing-masing poin tersebut, menampilkan ilustrasi berupa infografik dan foto untuk memudahkan dalam memberikan pemahaman bagi pembaca.

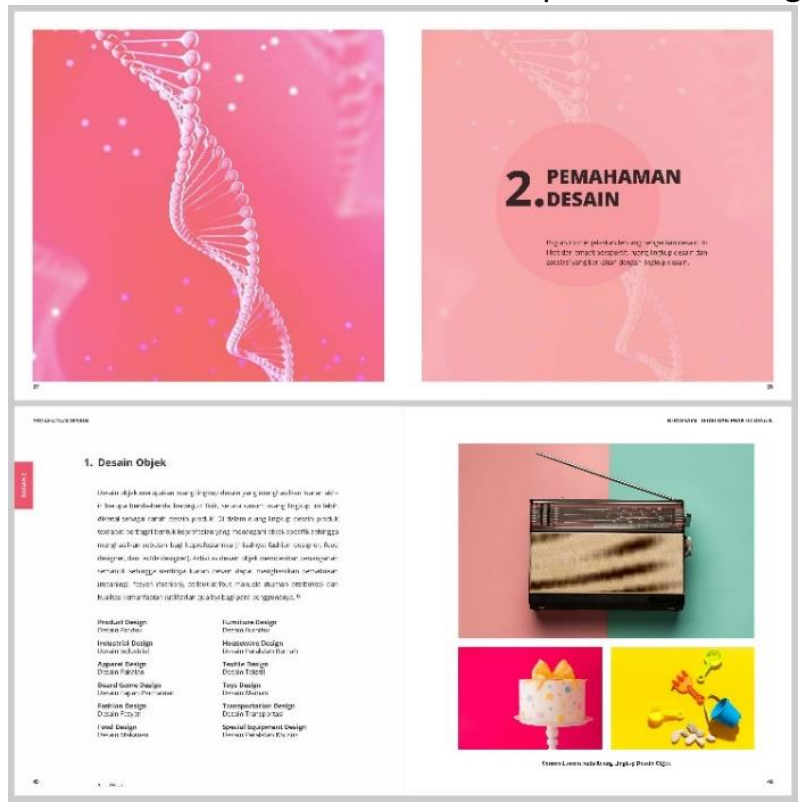

Gambar 8 Bagian Kedua - Pemahaman Desain

\section{Bagian 03 - Faktor Desain Alamiah}

Bagian ini membahas faktor desain yang bersifat alamiah dan menjadi bahan pertimbangan dalam menentukan keputusan di dalam proses desain. Faktor alamiah yang menjadi bahan pertimbangan desain dapat dikategorikan menjadi dua, yaitu: 1) faktor lingkungan, yang menampilkan ilustrasi untuk menggambarkan struktur permukaan bumi, aktifitas permukaan bumi, kondisi perairan, keanekaragaman hayati, iklim dan cuaca, 2) faktor manusia, yang menampilkan ilustrasi tentang gender, bentuk tubuh, bentuk kepala, bentuk wajah, bentuk hidung, karakter kulit, karakter mata, karakter rambut, karakter mulut, karakter telinga. Semua ilustrasi ditampilkan dalam susunan layout yang bervariasi.

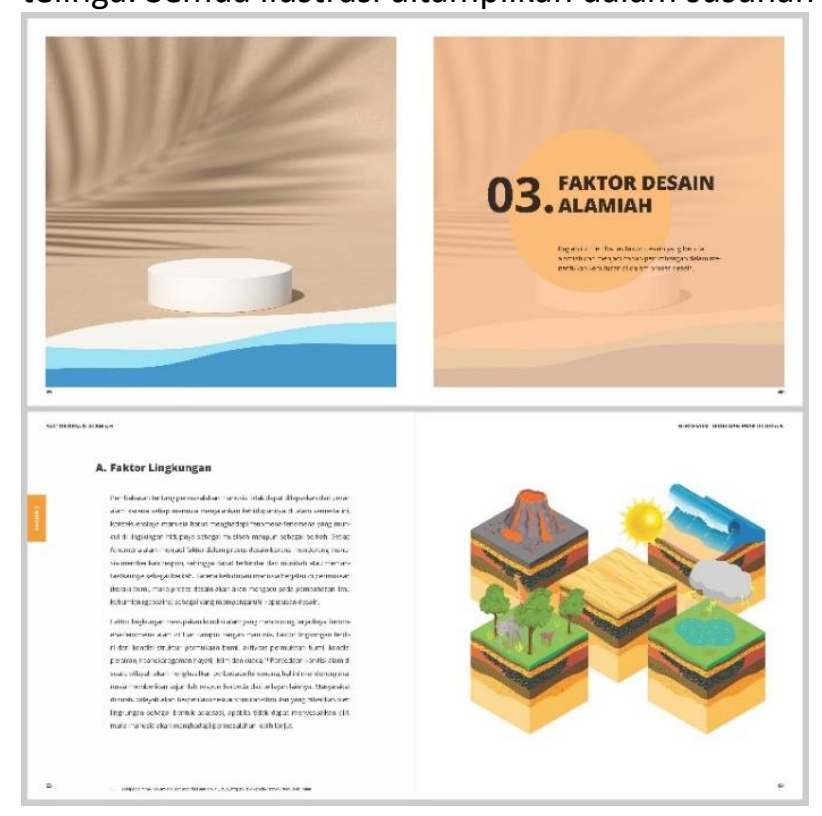

Gambar 9 Bagian Ketiga - Faktor Desain Alamiah 


\section{Bagian 04 - Faktor Desain Artifisial}

Bagian ini membahas faktor desain yang bersifat artifisial dan menjadi bahan pertimbangan dalam menentukan keputusan di dalam proses desain. Terdapat tujuh unsur kebudayaan yang akan diuraikan dalam bagian ini, yaitu: 1) religi, 2) pengetahuan, 3) teknologi, 4) sistem (organisasi) sosial, 5) ekonomi, 6) Bahasa dan 7) kesenian. Ilustrasi yang dimunculkan adalah berupa infografis dan foto. Sama seperti pada bagian sebelumnya bahwa semua ilustrasi ditampilkan dalam susunan layout yang bervariasi.

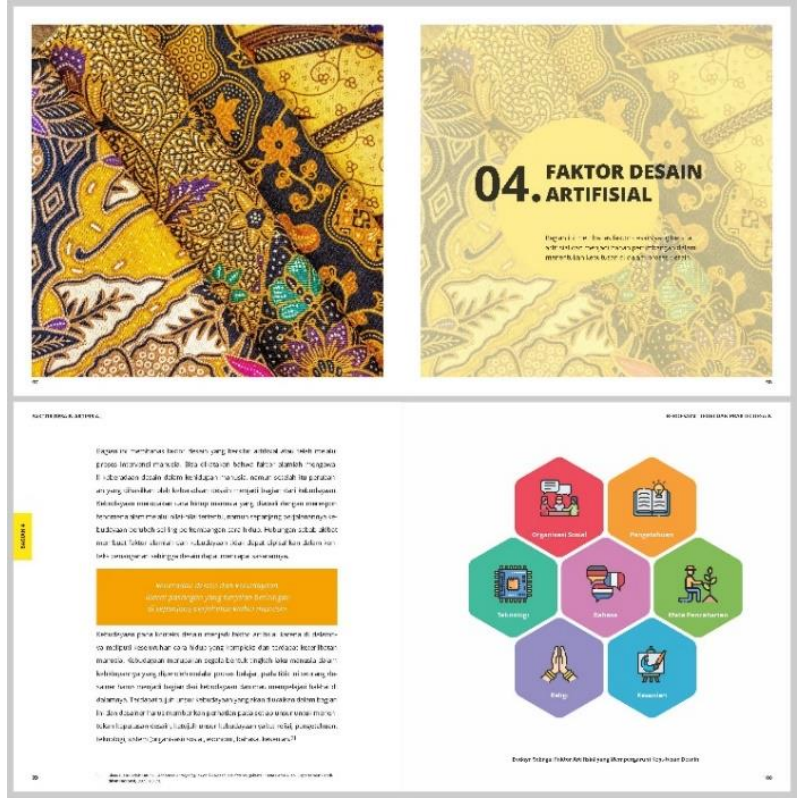

Gambar 10 Bagian Keempat - Faktor Desain Artifisial

\section{Bagian 05 - Tujuan Desain}

Bagian ini menjelaskan menjelaskan tentang hal-hal yang berusaha dicapai oleh seseorang melalui pemanfaatan suatu luaran desain. Tujuan desain dikaitkan dengan manfaat dari suatu luaran desain, yaitu: 1) mengakomodir kebutuhan, digambarkan dengan ilustrasi tentang contoh-contoh yang berkaitan dengan kebutuhan fisiologis, rasa aman, kasih sayang, harga diri, aktualisasi diri dan nilai, 2) mengakomodir nilai, menampilkan ilustrasi tentang nilai penghargaan diri, stimulasi, hedonism, pencapaian, kekuatan, keamanan, kesesuaian, tradisi, kebaikan, dan universalisme, 3) mengakomodir makna, ilustrasi ditampilkan beberapa contoh tentang makna denotatif, makna konotatif dan mitos. 


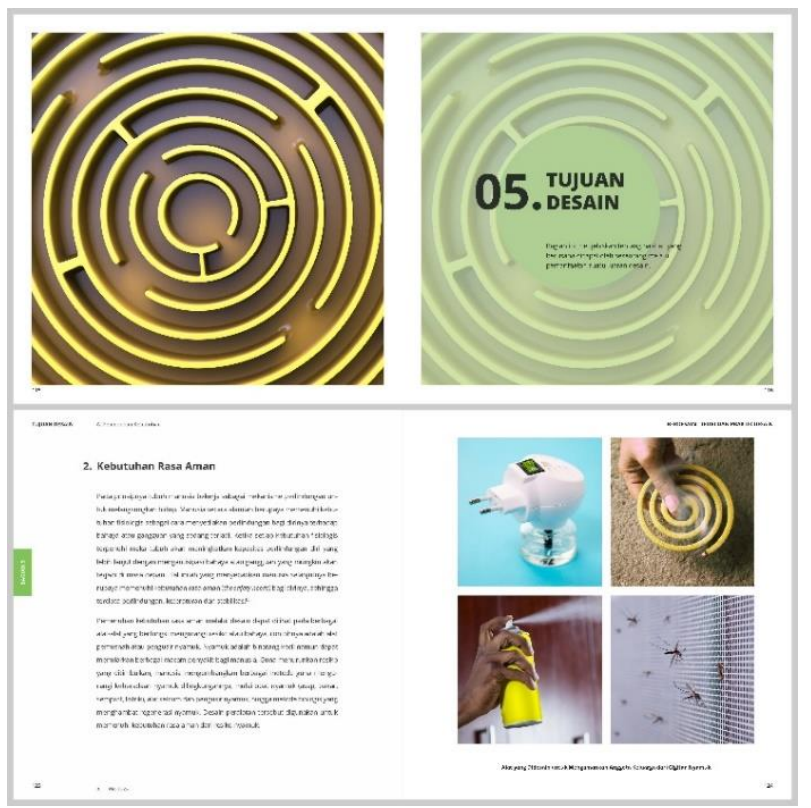

Gambar 11 Bagian Kelima - Tujuan Desain

\section{Bagian 06 - Fungsi Desain}

Bagian ini menjelaskan tentang fungsi (proses, aksi atau tugas) yang harus ada dalam suatu luaran desain sehingga pengguna dapat mencapai tujuannya. Secara ilustrasi pada bagian ini memberikan gambaran mengenai fungsi desain terhadap 1) keindahan, 2) kebergunaan, 3) keselamatan, 4) aksesibilitas, 5) keterjangkauan, 6) keberlanjutan, 7) ketahanan, 8) identitas, 9) emosional, dan 10) simbolisasi.

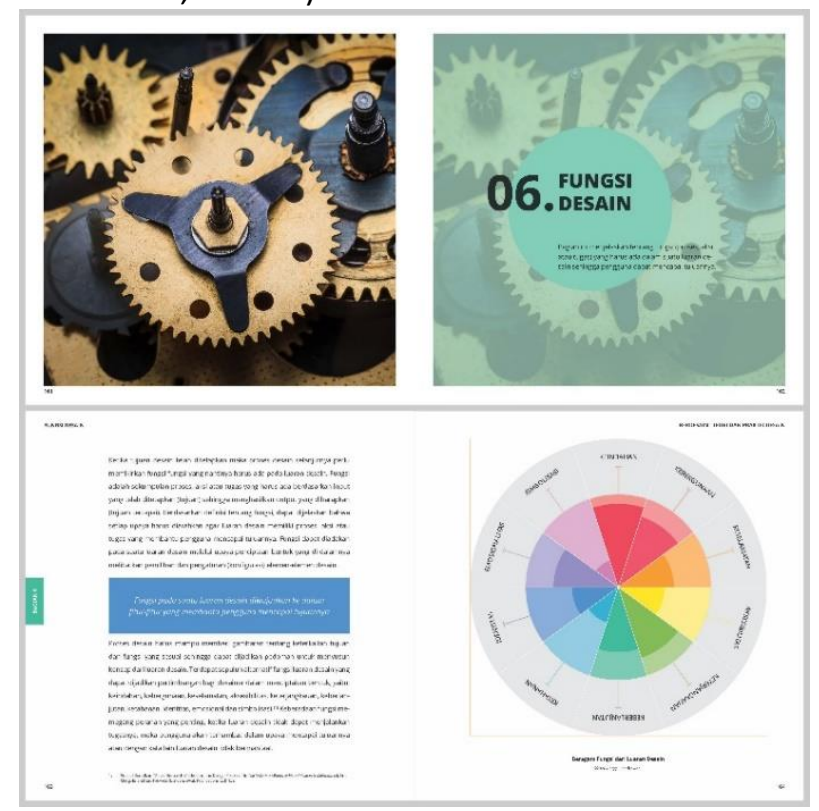

Gambar 12 Bagian Keenam - Fungsi Desain

Bagian 07 - Elemen Desain

Bagian ini menjelaskan tentang elemen-elemen yang digunakan untuk membangun wujud dari luaran desain agar dapat menjalankan fungsinya. Khusus pada bagian ini, ilustrasi akan lebih banyak menampilkan bentuk-bentuk bidang vector. 1) elemen abstrak, bidang-bidang vector untuk menunjukkan contoh tentang titik, garis, permukaan, volume, dimensi dan format, 
2) atribut elemen yang terdiri dari bentuk, ukuran, dan warna, 3) struktur elemen meliputi abstrak-konkret, formal-informal, aktif-nonaktif, halus-kasar, arah, gradasi, radiasi, kemiripan, tekstur, dan kerangka struktural, 4) reproduksi elemen terdiri dari repetisi, mencerminkan, rotasi, pergerakan, perbesaran, dan pemindahan, 5) relasi elemen antara lain latar depanbelakang, simetris-asimetris, tarikan-statis, negatif-positif, transparan-buram, kesetimbangan, grup, difusi, posisi, ruang, berat, dominasi, netral, koordinasi, jarak, paralel, sudut, titik singgung, tumpang tindih, gabungan, substraksi, koinsiden, penetrasi, ekstruksi, pengaruh, modifikasi, dan variasi. Pada poin kedua hingga kelima juga ditampilkan beberapa contoh-contoh berupa ilustrasi foto untuk memudahkan pemahaman bagi pembaca.

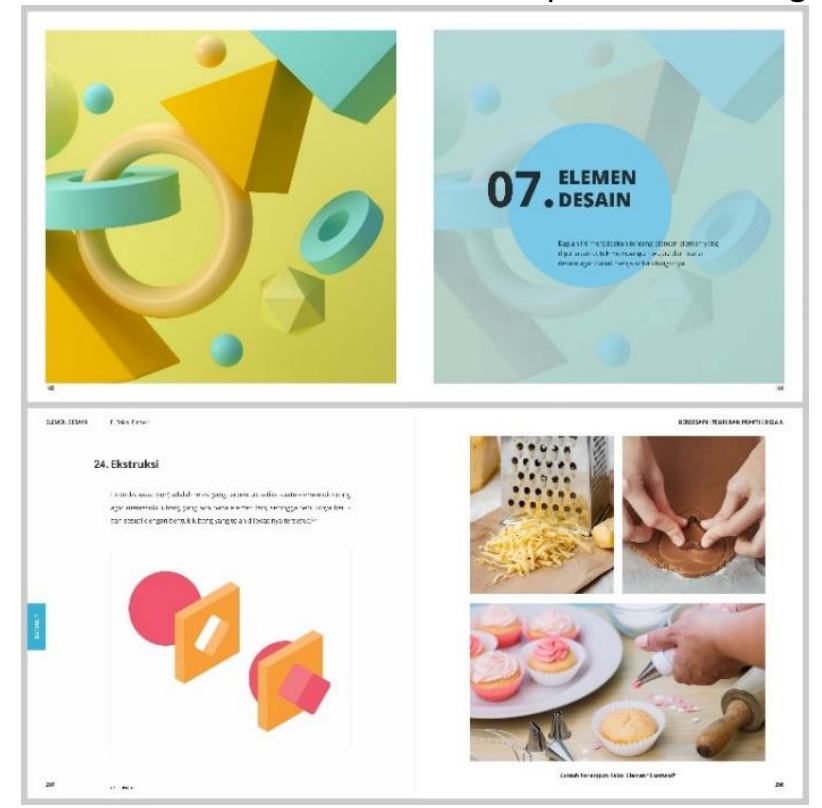

Gambar 13 Bagian Ketujuh - Elemen Desain

\section{Bagian 08 - Proses Desain}

Bagian ini menjelaskan tentang rangkaian prosedur yang dilakukan untuk menghasilkan luaran desain guna menyelesaikan permasalahan pengguna. Proses desain berupa siklus desain yang dimulai dari 1) penetapan masalah, 2) pengumpulan informasi, 3) penciptaan ide, 4) membangun purwarupa, 5) penentuan pilihan, 6) implementasi, dan 7) evaluasi. Ketujuh tahap yang merupakan metode Design Thinking tersebut lebih banyak menampilkan ilustrasi berupa tabel, bagan dan infografik sebagai media untuk menjelaskan keterangan secara detil. 


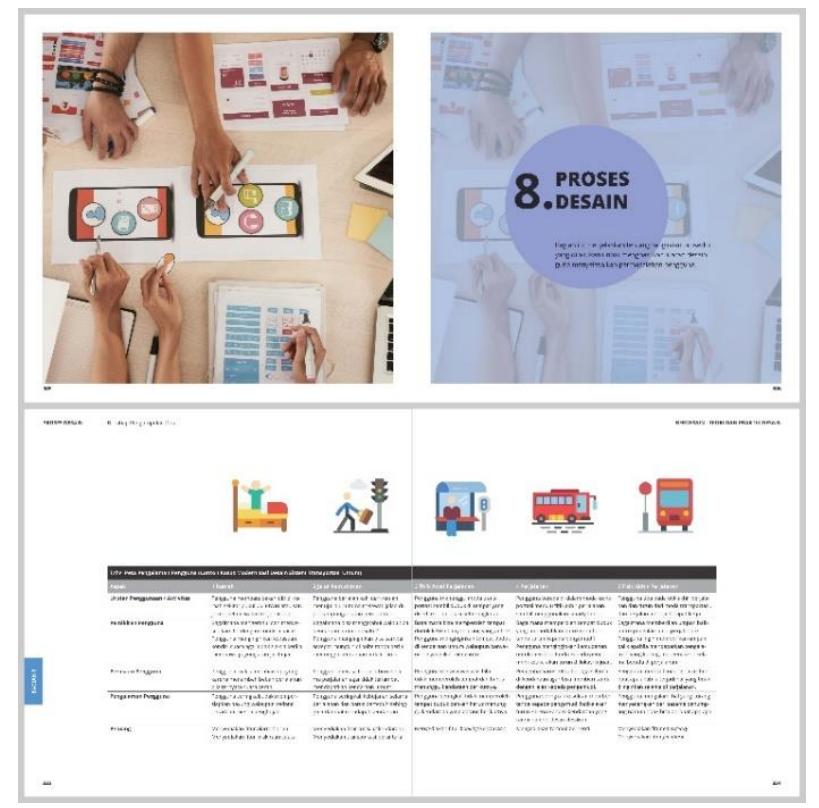

Gambar 14 Bagian Kedelapan - Proses Desain

\section{Bagian 09 - Perangkat Desain}

Bagian ini menjelaskan jenis-jenis perangkat desain dan fungsinya untuk membantu mewujudkan ide solusi. Yaitu 1) perangkat konvensional yaitu media menggambar, alat tulis, alat warna, pengukur, alat khusus, dan alat pendukung, 2) perangkat elektronik yaitu komputer, kamera, calibrator, digitizer, scanner, printer, mesin CNC, dan pencahayaan, 3) perangkat lunak yaitu software animasi, antarmuka, audio-visual, pemodelan, penerbitan, raster, dan vector, 4) perangkat intelektual yaitu hak cipta, paten, merek, desain industri, desain tata letak sirkuit terpadu, rahasia dagang, indikasi geografis. Ilustrasi yang dominan di bagian ini secara fotografis berupa gambar produk perangkat.

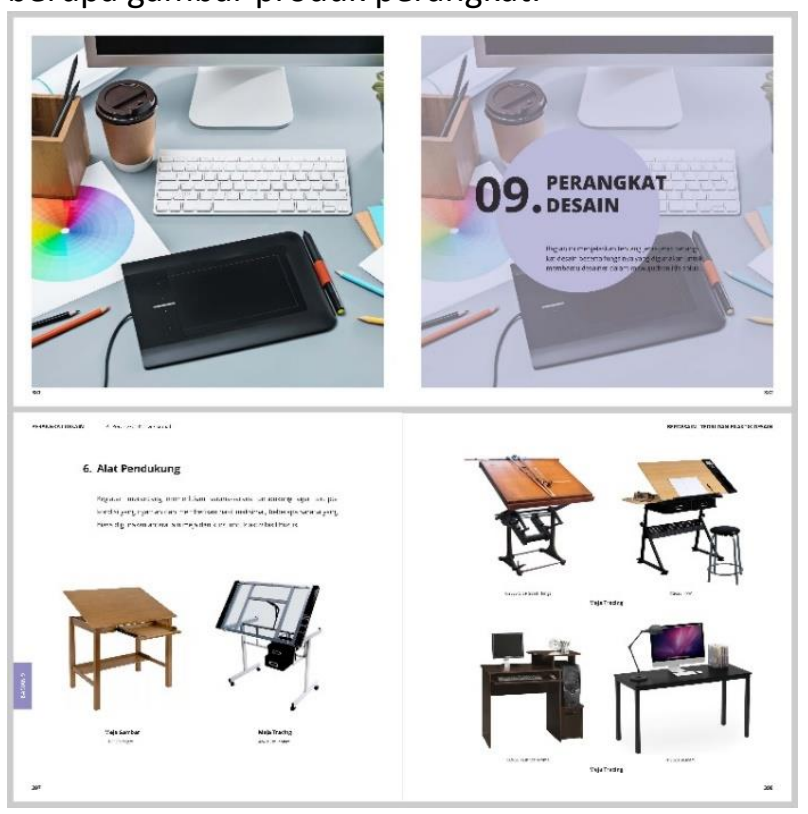

Gambar 15 Bagian Kesembilan - Perangkat Desain 


\section{Bagian 10 - Penutup}

Bagian ini menjelaskan tentang kesimpulan sekaligus saran dari penulis sehingga desainer dapat berproses dan berkontribusi dalam perkembangan desain. Ilustrasi hanya digunakan sebagai penguat penjelasan terhadap poin kesimpulan dan saran, serta sebagai identitas penulis.

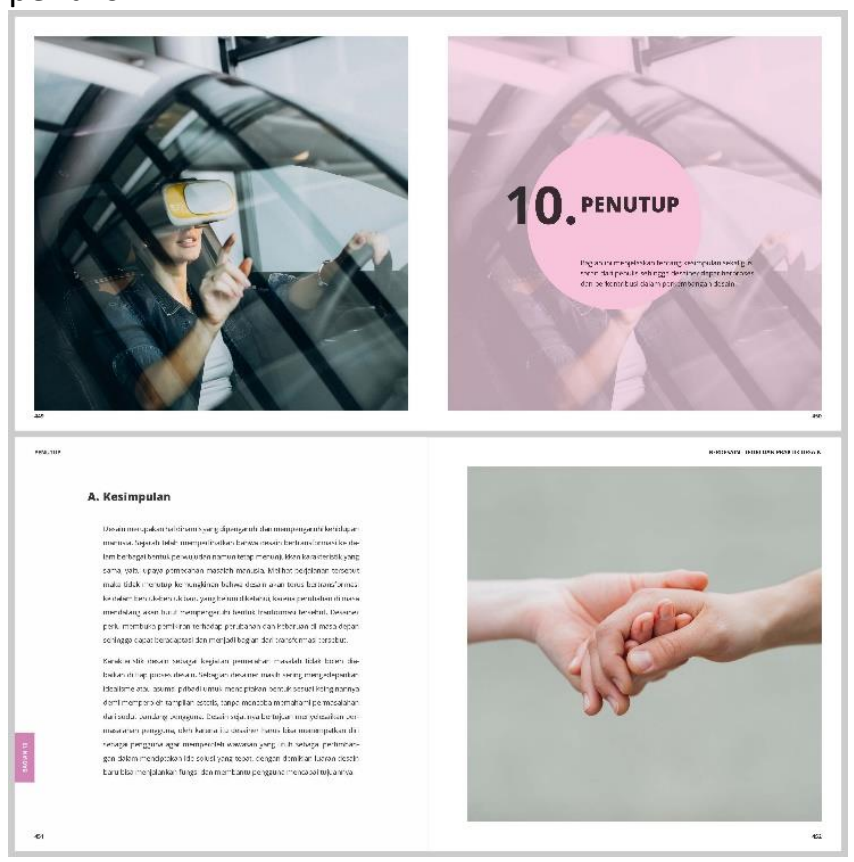

Gambar 16 Bagian Kesepuluh - Penutup

Purwarupa buku ilustrasi Berdesain diimplementasikan dan diujicobakan kepada mahasiswa sebagai target pengguna. Setelah dilakukan tahap implementasi, langkah berikutnya melakukan penilaian terhadap hasil uji coba prototipe dengan menggunakan metode kuesioner kepada responden. Berikut hasil pengolahan data berdasarkan frekuensi relatif (\%):

Tabel 2 Hasil Uji Coba Prototipe.

\begin{tabular}{|c|c|c|c|c|c|}
\hline Variabel & STS & TS & $\mathrm{N}$ & $S$ & SS \\
\hline \multicolumn{6}{|l|}{ Fungsional } \\
\hline $\begin{array}{l}\text { Buku ilustrasi Berdesain mampu menjadi literatur tentang } \\
\text { bidang keilmuan desain secara lengkap dan terpadu. }\end{array}$ & 0 & 0 & $10.7 \%$ & $35.7 \%$ & $53.6 \%$ \\
\hline $\begin{array}{l}\text { Buku ilustrasi Berdesain berfungsi sebagai media ajar yang } \\
\text { sesuai dan direkomendasikan. }\end{array}$ & 0 & 0 & $14.3 \%$ & $67.9 \%$ & $17.9 \%$ \\
\hline $\begin{array}{l}\text { Buku ilustrasi Berdesain dapat menjadi buku pegangan kuliah } \\
\text { bagi mahasiswa jurusan desain khususnya di semester awal. }\end{array}$ & 0 & 0 & $7.1 \%$ & $50 \%$ & $42.9 \%$ \\
\hline $\begin{array}{l}\text { Buku ilustrasi Berdesain sangat bermanfaat bagi para siswa, } \\
\text { mahasiswa, desainer dan siapapun yang ingin berkecimpung di } \\
\text { dunia desain. }\end{array}$ & 0 & 0 & $3.6 \%$ & $32.1 \%$ & $64.3 \%$ \\
\hline \multicolumn{6}{|l|}{ Desain } \\
\hline $\begin{array}{l}\text { Buku ilustrasi Berdesain merupakan media pembelajaran yang } \\
\text { memiliki tampilan/desain sangat menarik. }\end{array}$ & 0 & 0 & 0 & $25 \%$ & $75 \%$ \\
\hline $\begin{array}{l}\text { Pilihan komposisi warna, penggunaan jenis font dan tata Layout } \\
\text { sangat menarik dan konsisten. }\end{array}$ & 0 & 0 & 0 & $42.9 \%$ & $57.1 \%$ \\
\hline $\begin{array}{l}\text { Tampilan setiap ilustrasi yang terdapat dalam setiap bagian buku } \\
\text { memiliki kesesuaian, menarik dan mudah dikenali. }\end{array}$ & 0 & 0 & 0 & $39.3 \%$ & $60.7 \%$ \\
\hline
\end{tabular}


Perpaduan antara teks dan gambar memiliki hubungan dan

0

0

$7.1 \% \quad 39.3 \% \quad 53.6 \%$

keterkaitan yang kuat dan jelas dalam mendukung penyampaian

informasi.

\section{Efektivitas}

Buku ilustrasi Berdesain mampu memberikan pengetahuan dan wawasan yang luas di bidang keilmuan desain.

Materi dalam buku ilustrasi Berdesain sebagai buku ajar disajikan secara lengkap dan sistematis pada setiap BABnya.

Konten materi dan penggunaan bahasa yang disajikan dalam

setiap bab sangat informatif, padat dan jelas, sehingga mudah dipelajari dan dipahami bagi pembaca.

$\begin{array}{llllllll}\text { Kehadiran Buku ilustrasi Berdesain diharapkan mampu } 0 & 0 & 21.4 \% & 50 \% & 28.6 \%\end{array}$ memotivasi para mahasiswa dalam belajar dan mendalami keilmuan desain.

Sumber: Penulis.

Dari hasil penilaian dapat disimpulkan bahwa: 1) Dari segi fungsional bahwa lebih dari $80 \%$ responden mendukung bahwa buku ilustrasi Berdesain mampu menjadi literatur tentang bidang keilmuan desain secara lengkap dan terpadu, sehingga media ini bermanfaat bagi mahasiswa dan siapapun yang ingin berkecimpung di dunia desain. 2) Dari segi desain bahwa $100 \%$ responden setuju dan sangat setuju bahwa buku ilustrasi Berdesain merupakan media pembelajaran yang memiliki desain sangat menarik. 3) Dari segi efektivitas media bahwa lebih dari $90 \%$ responden juga mendukung bahwa buku ilustrasi Berdesain mampu memberikan pengetahuan serta mudah dipelajari dan dipahami bagi pembaca.

\section{Simpulan}

Desain sebagai cabang keilmuan, melibatkan pelbagai cabang keilmuan lainnya. Desain menjadi salah satu bidang ilmu pendidikan tinggi di Indonesia yang terus mengalami peningkatan. Hal ini tercermin dari banyaknya perguruan tinggi negeri atau swasta yang membuka program studi pada bidang ilmu desain. Peningkatan minat terhadap pendidikan desain harus diikuti dengan keberadaan literatur yang memadai. Literatur yang seharusnya adalah yang dapat memberikan perspektif lebih luas tentang desain dan interkoneksinya dengan bidang keilmuan lainnya.

Penelitian ini dilakukan untuk menghasilkan purwarupa berupa buku ilustrasi sebagai buku literatur yang berbeda dengan buku literatur pada umumnya. Buku ilustrasi Berdesain diharapkan mampu menjadi sebuah literatur bidang keilmuan desain yang lengkap, terpadu, mampu membuka gambaran utuh tentang bidang ilmu desain dan efektif bagi mahasiswa jurusan desain khususnya pada semester awal sebagai media pembelajaran yang menarik untuk dipelajari, mudah dipahami, sehingga dapat meningkatkan motivasi minat belajar serta pendalaman keilmuan desain. Buku ilustrasi Berdesain diharapkan bermanfaat bagi mahasiswa dan siapapun yang ingin berkecimpung di dunia desain.

\section{Ucapan Terima Kasih}

Terima kasih kepada Direktorat Riset dan Pengabdian Masyarakat, Direktorat Jenderal Penguatan Riset dan Pengembangan, Kementerian Ristek-BRIN Republik Indonesia yang telah 
membiayai penelitian ini melalui skema Hibah Penelitian Dosen Pemula Tahun Anggaran 2020 sesuai dengan Kontrak Penelitian No. 004/SP2H/LT/P3M/IKADO/III/2020.

\section{Daftar Pustaka}

123desaingrafis. 2013. "Pengertian Desain lingkungan." desain (blog). 5 Agustus. http://123desaingrafis.blogspot.com/2013/12/pengertian-desain-

lingkungan.htm|\#: : text=Desain\%20lingkungan\%20adalah\%20proses\%20menangani,k ebijakan\%20\%2C\%20bangunan\%20\%2C\%20atau\%20produk\%20.\&text=Desain\%20ling kungan\%20juga\%20dapat\%20merujuk,dengan\%20menciptakan\%20lingkungan\%20ma nusia\%20dirancang\%20.

Alodia, Audrey Diwantri. 2019. "Desain sebagai Jembatan dan Identitas Perusahaan." Yukomikus. Accessed 5 Agustus. https://yukomikus.com/2019/07/19/desain-sebagaijembatan-dan-identitas-perusahaan/.

Ambrose, Gavin, and Paul Harris. 2010. Basics Design 08: Design Thinking. Switzerland: AVA Publishing.

Arifin, Syamsul, and Adi Kusrianto. 2009. Sukses Menulis Buku Ajar dan Rerefensi. Jakarta: Grasindo.

Brown, Tim, and Jocelyn Wyatt. 2010. "Design Thinking for Social Innovation." Development

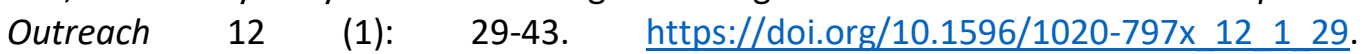
https://elibrary.worldbank.org/doi/abs/10.1596/1020-797X 12129 \%X Designers have traditionally focused on enchancing the look and functionality of products.

Buchanan, Richard. 1995. "Rhetoric, Humanism and Design." In Discovering Design: Explorations in Design Studies, edited by Richard Buchanan and Victor Margolin. Chicago: University of Chicago Press.

Chaeruman. 2008. Mengembangkan Sistem Pembelajaran dengan Model ADDIE. Jakarta: PT. Remaja Rosdakarya.

Giard, Jacques. 2016. The Contextual Nature of Design and Everyday Things. Kendall Hunt Publishing Company.

Ingle, Beverly Rudkin. 2013. Design Thinking for Entrepreneurs and Small Businesses: Putting the Power of Design to Work. Apress.

Lukman, Christine, Alvanov Zpalanzani, Nina Nurviana, Wina Nur Alia, and Arifin Nugraha. 2009. Bahasa Rupa pada Buku Ilustrasi Anak Indonesia Kontemporer: Studi Kasus Seri Cerita Pelangi Gramedia Pustaka Utama (GPU). Desain Komunikasi Visual Fakultas Seni Rupa dan Desain, Universitas Kristen Maranatha (Bandung). https://repository.maranatha.edu/385/.

Piliang, Yasraf Amir. 2010. "Desain, sejarah, budaya: Sebuah pengantar komprehensif." In Desain, sejarah, budaya, edited by John A Walker. Yogyakarta: Jalasutra. 
Sachari, Agus, and Yan Yan Sunarya. 2000. Wacana Transformasi Budaya. Bandung: Penerbit ITB.

---. 2001. Pengantar Tinjauan Desain. Bandung: Penerbit ITB.

Saifudin, Fahmi. 2013. "Pemahaman Publik Terhadap Desain Visual Sebagai Alat Komunikasi Yang Efektif." Sinteks: Jurnal Teknik 2 (1). https://jurnal.stt.web.id/index.php/Teknik/article/view/19.

Sakti, Zein. 2018. "Proses Penciptaan Desain dan 5 Prinsipnya." awalilmu.com. Accessed 5 Agustus. $\quad$ https://www.awalilmu.com/2018/08/proses-penciptaan-desain-dan-5prinsipnya.html.

seputarpengetahuan.co.id. 2017. "Pengertian Desain, Fungsi, Tujuan, Jenis, Prinsip, Manfaat \& Metode." Portal Media Pengetahuan Online Seputar Pengetahuan (blog), seputarpengetahuan.co.id. 5 Agustus. https://www.seputarpengetahuan.co.id/2017/11/pengertian-desain-fungsi-tujuanjenis-jenis-prinsip-manfaat-metode.html.

Thabroni, Gamal. 2019. "Pengertian Desain (Lengkap) berdasarkan Pendapat Para Ahli." serupa.id. Accessed 4 Agustus. https://serupa.id/pengertian-desain/. 